Published titles

IMPROVISATION IN DRAMA

Anthony Frost and Ralph Yarrow

NEW DIRECTIONS IN THEATRE

Julian Hilton

Forthcoming titles

REPRESENTATION AND THE ACTOR

Gerry McCarthy

SEMIOTICS OF THE DRAMATIC TEXT

Susan Melrose

TRANSPOSING DRAMA

Egil Tornquist 


\section{Improvisation in Drama}

ANTHONY FROST and RALPH YARROW

Macmillan Education 
ISBN 978-0-333-38821-1 ISBN 978-1-349-20948-4 (eBook)

DOI 10.1007/978-1-349-20948-4

(C) Anthony Frost and Ralph Yarrow, 1989

Softcover reprint of the hardcover 1st edition 1989 978-0-333-38820-4

All rights reserved. For information, write:

Scholarly and Reference Division,

St. Martin's Press, Inc., 175 Fifth Avenue,

New York, N.Y. 10010

First published in the United States of America in 1990

\section{ISBN 978-0-312-04746-7}

Library of Congress Cataloging-in-Publication Data

Frost, Anthony.

Improvisation in drama/by Anthony Frost and Ralph Yarrow.

p. cm. - (New directions in theatre)

Includes bibliographical references (p. ).

ISBN 978-0-312-04746-7

1. Improvisation (Acting) I. Yarrow, Ralph. II. Title.

III. Title: Improvisation in drama. IV. Series.

PN2071.15F76 1990

792'.028-dc20

90-8114

CIP 


\section{Contents}

List of Plates vii

General Editor's Preface viii

Acknowledgements ix

Introduction 1

Definitions $\quad 1$

Early history: shamans, clowns and actors 4

PART I WHO? MAJOR PRACTITIONERS OF IMPROVISATION

1 Improvisation in Traditional Drama 13

Introduction - the principle of improvisation $\quad 13$

Overview 14

Precursors: Stanislavsky and Meyerhold 15

Jacques Copeau $\quad 20$

Le Théâtre du Soleil 30

Improvisation and 'traditional' theatre training 31

Mike Leigh $\quad 37$

Further thoughts on play-construction using improvisation $\quad 42$

New York Giants versus Chicago Bears 45

2 Improvisation in Alternative Drama 55

Roddy Maude-Roxby/Theatre Machine 55

Jacques Lecoq and the semiotics of clowning 61

Dario Fo and Franca Rame $\quad 73$

3 Beyond Drama - 'Paratheatre' 83

Jerzy Grotowski $\quad 83$

PART II WHAT? THE PRACTICE OF IMPROVISATION: IMPROVISATION EXERCISES

Introduction $\quad 95$

4 Preparation $\quad 97$

Relaxation $\quad 97$

Games $\quad 97$

Balance and 'body/think' $\quad 98$

Space and movement 100

Concentration and attention 101

$\begin{array}{ll}\text { Impulses and directions } & 103\end{array}$ 
5 Working Together 105

Trust and respect $\quad 105$

Making a machine $\quad 106$

$\begin{array}{ll}\text { Showing and telling } & 107\end{array}$

$\begin{array}{ll}\text { Entrances and exits } & 108\end{array}$

$\begin{array}{ll}\text { Meetings and greetings } & 109\end{array}$

$\begin{array}{ll}\text { Blocking } & 110\end{array}$

6 Moving Towards Performance 112

$\begin{array}{ll}\text { Senses } & 112\end{array}$

Tenses $\quad 113$

Status $\quad 114$

Masks $\quad 116$

Masks - another view $\quad 121$

7 Applied Improvisation Work 126

Who/where/what $\quad 126$

$\begin{array}{ll}\text { Objectives and resistances } & 127\end{array}$

Point of concentration (focus) 128

$\begin{array}{ll}\text { Memory } & 129\end{array}$

'Set' 130

Character $\quad 131$

Narrative $\quad 134$

PART III WHY? THE MEANINGS OF IMPROVISATION: TOWARDS A POETICS

Introduction

8 Enriching the Communication of Meaning

Implications of psychodrama and paratheatrical approaches

The censor's nightmare $\quad 146$

La disponibilité $\quad 151$

Transformation $\quad 155$

9 Meaning and Performance 165

Some aspects of meaning in performance $\quad 165$

Texts, signs and meaning 166

$\begin{array}{ll}\text { Co-creativity } & 169\end{array}$

Gremlin's Theatre $\quad 175$

New combinations $\quad 179$

$\begin{array}{lr}\text { Notes } & 182\end{array}$

Bibliography 199

Index 206 


\section{List of Plates}

1. I Gelati in Commedia masks (photograph courtesy of I Gelati)

2. Copeau's Comédie Nouvelle: Saint-Denis as Knie, Suzanne Bing as La Célestine, Dasté as César (photograph courtesy of Et. Bordas, from J. Lecoq (ed.), Le Théâtre du Geste, 1988)

3. Jacques Lecoq in neutral mask (photograph courtesy of Patrick Lecoq)

4. Lecoq teaching at his Paris school (photograph courtesy of Et. Bordas, from J. Lecoq (ed.), Le Théatre du Geste, 1988)

5. 'The fight in the dark', from The 1984 Game, University of East Anglia, 1983 (photograph courtesy of Anthony Frost)

6. Free improvisation with Roddy Maude-Roxby (Theatre Machine) (photograph courtesy of Jo Rice)

7. Théâtre de Complicité in Please Please Please (photograph courtesy of Théâtre de Complicité)

8. 'Croquet': Ric Morgan and Roddy Maude-Roxby (Theatre Machine) 1981 (photograph courtesy of Bernard Phillips) 


\section{General Editor's Preface}

In the past ten years, Theatre Studies has experienced remarkable international growth, students seeing in its marriage of the practical and the intellectual a creative and rewarding discipline. Some countries are now opening school and degree programmes in Theatre Studies for the first time; others are having to accommodate to the fact that a popular subject attracting large numbers of highly motivated students has to be given greater attention than hitherto. The professional theatre itself is changing, as graduates of degree and diploma programmes make their way through the 'fringe' into established theatre companies, film and television.

Two changes in attitudes have occurred as a result: first, that the relationship between teachers and practitioners has significantly improved, not least because many more people now have experience of both; secondly, that the widespread academic suspicion about theatre as a subject for study has at least been squarely faced, if not fully discredited. Yet there is still much to be done to translate the practical and educational achievements of the past decade into coherent theory, and this series is intended as a contribution to that task. Its contributors are chosen for their combination of professional and didactic skills, and are drawn from a wide range of countries, languages and styles in order to give some impression of the subject in its international perspective.

This series offers no single programme or ideology; yet all its authors have in common the sense of being in a period of transition and debate out of which the theory and practice of theatre cannot but emerge in a new form. 


\section{Acknowledgements}

Thanks to a variety of editorial hands at Baker-Mahaffy and Macmillan, and in particular to our colleague and General Editor, Julian Hilton, for his encouragement and most valuable comments. We also owe a considerable debt of gratitude to performers we have talked to and worked with, especially Jacques Lecoq, Roddy Maude-Roxby (Theatre Machine), James MacDonald and Malcolm Tulip (I Gelati), Simon McBurney and Clive Mendus (Théâtre de Complicité), Rena Mirecka (Teatr Laboratorium), and our friend and colleague Franc Chamberlain (who has also read and commented on part of the book). Thanks also to several generations of UEA drama students; and to those from whom we have learned or continue to learn in other contexts: Nicholas Brooke, Douglas Brown, Max Flisher, Tony Gash, Tony Hall, Clive Barker, David Hirst, Amanda Frost and Jackie Yarrow. 
For Simric and Kielan Yarrow

and

for William Frost and in memoriam

Kathleen Frost 